\title{
Dance as a contemplative practice
}

\section{The space of distinction and union}

\author{
DOI: https://doi.org/10.30664/ar.98065
}

Attribution 4.0 International (CC BY 4.0)
T his article analyses ethnographic material gathered in Sweden amongst dancers in the Church of Sweden. With the help of the writings of Sarah Coakley and Simone Weil I explore if, and how, dancing could be considered a contemplative practice in the Christian traditions of the Latin West.

When asked why they dance, more than one of my companions state that it is because, in dance, the physical and the spiritual are united.

It is in the circle dance practice that the two most important aspects of my life and the world - the body and the soul or spirit - are woven together uniquely. A space is created where I can sense that everything is whole. In the dance, body, emotions, and spirit are united - and most importantly, a community and sense of belonging to something bigger emerges. $(\text { LD AI 1 })^{1}$

1 Extract from ethnographic research material gathered in Sweden between the years 2014-16. 'LD' refers to people from a more traditional 'sacred circle dance' schooling, while ' $\mathrm{KR}$ ' are participants in a more experimental schooling where the method of teaching was dance. All materials have been completely anonymised in order to protect the people involved. The amount of dancers in the Church of Sweden is such

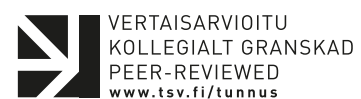

PEER-REVIEWED
www.tsv.fi/tunnus

It was only through finding a connection to my body - when I started dancing - that I found a way to perceive the presence of God in my life. I can also sense a connection through stories, dreams and visions - but only in exploring my bodily connection to deeper layers of self - could I hear God speak right through my intellectual defences. (KR BI 5)

'One of the tasks of the Church is to pronounce those things that other people do not say' Even when people may look at me weirdly I think it is my place to state that we may listen to, and follow, the Holy Spirit's guidance

a small group that no further information can be shared, except in which sessions and schoolings or interviews the material was gathered. The term 'BI' refers to a background survey made before the schoolings started, EI refers to external informants who are involved in dance but did not attend the schooling and 'AI' are in-depth interviews conducted after the course had ended and the fieldwork period was finished. Coding and classification has been done in the qualitative research program NVivo and the material is stored behind password protection only on the author's personal computer. 
in every small step of the day. This is also what I teach my ladies. I teach the dancers to be present in their bodies, to listen and be here in this moment. And I am happy that the leader of our congregation also has encouraged me to listen to, and be guided by, the Holy Spirit.

For me, it is essential that everybody can learn to listen to, and all of us can follow, the Spirit. And it is weird how we in the Lutheran church speak about the common priesthood, but then in practice, it's often only priests that are 'called'... However, as I see it, we can all be called, we can all learn to listen to the Spirit and thus we can also lead worship and prayer.

Personally, I sense that I am led and called to lead dances and do pilgrimage walks and other kinds of ritual-based practices. And I can sense the difference - when I listen to the Spirit and invite the Spirit to guide our sessions. Sometimes we have dance sessions that are more like services, then I prepare a text, some symbol or image, that we build our dances around. There too, I always listen to the guidance in building these sessions, and I feel I am given the right words and things to do. I think I have always functioned like this, but now when I work in the church, I sense that I am allowed to speak about it more openly.

Even when we have what basically could be considered 'only' a dance practice session, I commence the meeting by saying out silently to myself: 'Holy Spirit - be with us and guide us!' And I know it may sound simplistic or naive, but I can actually sense the difference! When I say this prayer, something shifts.
This is also what I tell my ladies, that even when we are here to practise - we are gathering for a specific purpose - we are here to listen to, and be with, God. I can see how they are growing - their capacity to be their own Selves, an increased sense of peace and presence in the here and now. Interestingly, the only time this shifts is when one of the priests joins us.

The priest comes when we have a service. Partly, it seems, to 'inspect' what we are doing. Partly, to just be participating. However, as the priest does not want to join us in the dance, I see how it really interrupts the flow. My ladies start to fumble and feel insecure. They lose even the most simple steps that they always know by heart. And there is this weird sense, that the priest is 'needed' in order for there to be a service... but, when the priest is there, everything just turns too 'heady', we lose the connection, and even I feel like I lose some of my capacity to listen, to be guided and follow what is given to me. Nowadays, I prefer doing the services on my own, or with the church musician. Even though the musician does not participate in the dancing, what is missing is the conflict between the priest being a service 'doer' and giving us 'the Word' and me guiding with my words, dance, prayerful movements and creating space for worship. (LD AI 4)

Here are only a few extracts from many stories where dancers have expressed to me a sense of connection between their bodies and God. These stories were shared by people I encountered through two different educational programmes in relation to the Church of Sweden, where dancing was 
a method of teaching. The dancers were people related somehow to congregations in the Church of Sweden - some of them were considered 'lay' and others working in various staff positions. The people I met during the course of this ethnographic fieldwork spoke about how they have encountered God, gained increased insight into important questions, and grown in their awareness of themselves and the world, through a variety of bodily activities - especially dancing.
In this article, I have two principal aims: to explore whether dancing could be understood as a contemplative practice within the framework of Christian traditions of theology in the Latin West; and, to demonstrate what could be learnt about Christian contemplation if it is studied from the viewpoint of dance and the experiences presented by dancers.

The first aim takes its starting point in the situation where many of the dancers expressed that they lacked a framework

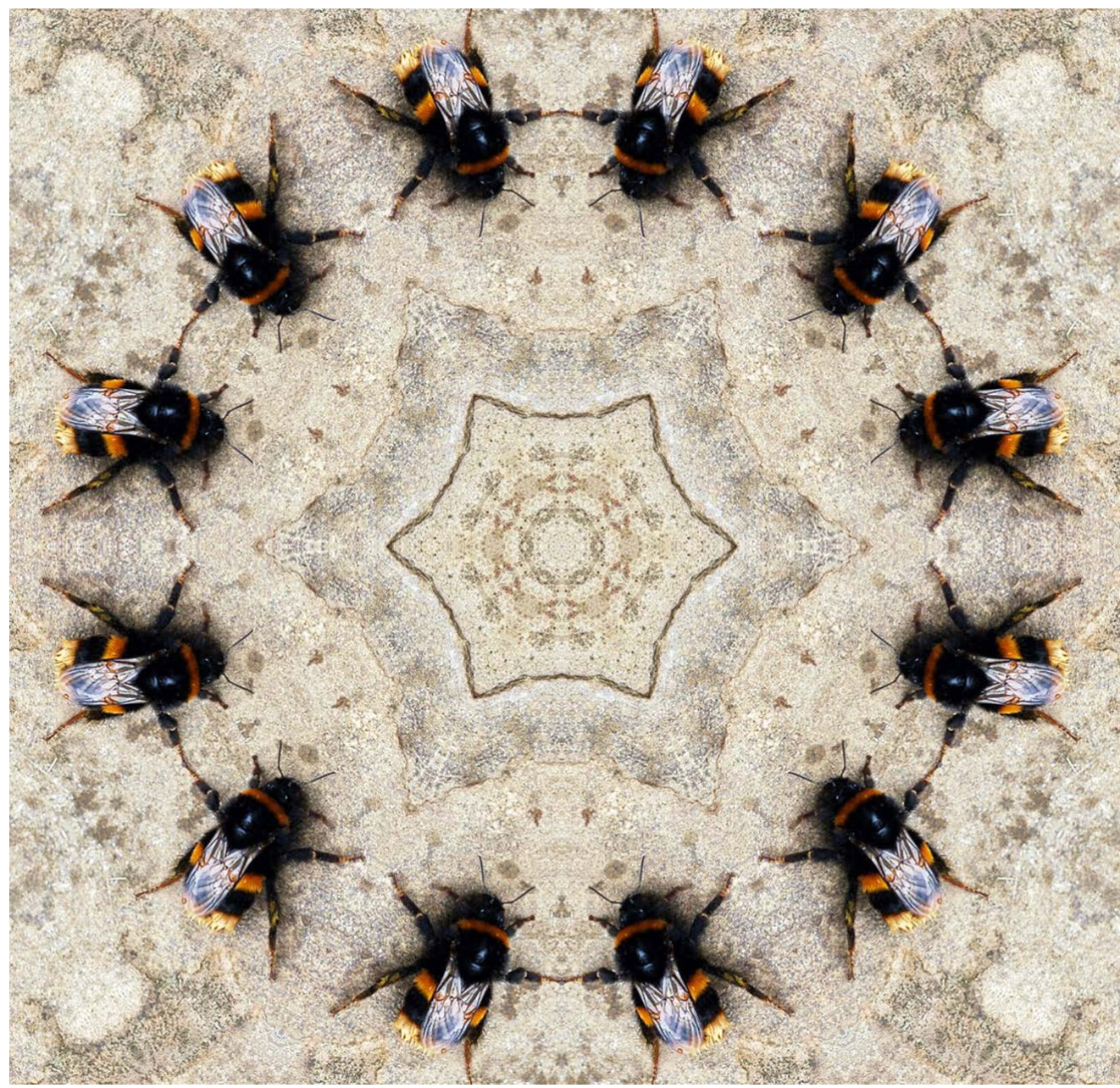

Sacred circle dances were initiated in the beginning of the 1990s by Maria Rönn in the Church of Sweden. She and a larger community of women started to implement community dances with simple and repetitive movements into the Church practices of prayer and meditation. In the community where I learnt these dances, often the middle of the circle contained a symbol that reminded us of the presence of God in and around the space we were in as well as in the dancing bodies. Photo: Pixabay. 
and terminology within which their practices and experience made sense, in a Christian context (LD 2.2.3, 2.4.2; KR $3.3 .2,5.3 .2,7.1 .2$; KR AI1 $){ }^{2}$ Often, the only context within which dancing had been explained in terms of carrying some sort of spiritual meaning was through Eastern meditation practices, or in relation to some somatic teachings such as that of G. I. Gurdjieff (c.1866-1949) or Rudolf Steiner (1861-1925). ${ }^{3}$ In the first part of the article, I will explore the links between dance and Christian contemplative practices in the Latin West.

When approaching the writings of current-day theologians such as Sarah Coakley on the theme of contemplation, it seems that dance is rarely considered to be part either of the traditions or the teachings exemplified. ${ }^{4}$ Some voices even claim that particularly European forms of Christianity are hostile towards dance (LaMothe 2018: 1-4). Contrary to these views, my second aim is to show that by studying dancers and dance, we might actually gain deeper

2 None of the dancers were aware of the writings or experiences of performers such as Isadora Duncan, Ruth St Denis or Martha Graham.

3 In relation to the discussions on mindfulness often also neuro-scientific studies on meditation and dance came up (LD EI S2; LD 1.2.3, 1.2.5.0). Furthermore, historically particularly a theosophically tainted understanding of 'the origins' of dance as a spiritual practice has been understood as the only tradition that supports dancing in Christian settings. See Adams and Apostolos-Cappadona 2001: 238; Taylor 2009: 192; Mead 1913 and my critical reading of these in Hellsten 2020: 73-83, 107-19, 146-8.

4 She writes particularly about contemplation in Powers and Submissions (2002), the Gifford lectures (2012), God, Sexuality and the Self' (2013), The New Asceticism (2015) and a lecture entitled 'Christian worship and desire' (2018). insights into some of the Christian teachings on contemplation.

My materials are mainly theoretical discussions of dance and contemplation, while the ethnographic materials provide examples in relation to lived experiences of dancers. However, one should not understand this set-up as a traditional division between theory and praxis. It is rather so that, along the lines of Sarah Coakley's théologie totale, this study is informed by the practices of dancers in the Church of Sweden and dance as a particular art form with semiotic abilities and an independent theological 'voice. ${ }^{5}$ Dancing itself is thus, in this article, considered as a mode of theological reflection.

\section{Introduction}

In the newest edition of the Spiritual Disciplines Handbook, 75 different practices are named as being part of a Christian path of transformation (Calhoun 2015: 13-16). Compared with the edition of 2005, one can now find even mindfulness on this list, but not dance. Dancing is mentioned in the section on celebration, but absent everywhere else (ibid. p. 30). Even though dancing may be a practice of communal worship and celebration, the stories I encountered in my fieldwork show that dancing is much more than that.

What is described by the dancers often comes much closer to what Nina Kokkinen writes, in Spiritual Treasures (Kokkinen and Nyström 2020), about esotericism. She states that esoteric practices build on

5 Coakley explains that a theology in via needs to dialogue between texts, social sciences and the arts. Thus, in her methodology she triangulates between ethnographic materials, textual discussions and art forms as equal and different 'voices' to be listened to (Coakley 2013: 33-100). 
the idea that there is some higher, hidden knowledge available for those who are willing to follow a certain plan and be initiated on a path. Furthermore, people that follow in the footsteps of that path and partake in the ritual enactments are transformed so that they can perceive the world and themselves in a new light (Kokkinen 2020: 8). This kind of general introduction fits well also with the descriptions found in other studies on the effects of, particularly, circle dancing.

In the field of occupational therapy, Ana L. Borges da Costa and Diane L. Cox interviewed dancers who make statements such as the following:

... when I'm doing circle dance, sometimes it transports you ... it is like magic really ... it is a bit difficult to explain ... first you are thinking about what you are doing, and then ... eventually ... I find that it is almost hypnotic ... and I float along ... you feel it [the dance] flowing through your body. It is amazing really ... it doesn't happen all the time ... I don't know why it happens sometimes and it doesn't happen at other times ... but sometimes the dance just flows and you just flow with the dance and you feel really good then. (Borges da Costa and Cox 2016: 202)

Dancing seems to transport people into altered states of being and experience at the same time as it connects them, somehow, to themselves and others. The dancers are changed, but how can we understand this? As the examples from the dancers I met show, many of them understand this connection to be related to God. There is no consensus amongst the dancers in the two groups about how to speak about these experiences. However, only a few of them would perhaps call themselves agnostic or spiritual, and clearly state that they feel most at home outside of the church, in an esoteric tradition. The vast majority did speak about God or the divine and go to church regularly. Thus, it would be unethical to approach their experiences from a framework where Christianity is seen as a 'hostile' force or something to push back against. Rather, the dancers are seeking a place within the church that accepts them and acknowledges their experiences.

The majority of writings about dance and theology in a more contemporary context focus on professional dancers such as Isadora Duncan (1877-1927), Ruth St Denis (1879-1968) and Martha Graham (1894-1991). Another option are dance companies, often active in the US, such as the pioneering work of Ted Shaw (Schwan 2017: 23 and 2019; LaMothe 2006: 269 and 2018: 124). Of the encounters I had in this study, none of the dancers were professional. Only a few of them had an earlier experience of some level of professional dance schooling, and even the leaders were more acquainted with dance therapy than actually focused on creating performances for a wider public.

This article thus focuses on the oftenneglected stories of people who experience dancing as part of their spiritual formation, religious expression, prayer and spiritual community engagement. It is for this reason that I find that Sarah Coakley's théologie totale lends itself well as a methodological framework for my study. She states that her method is one that wants to engage with what has been hidden, and earlier marginalised views in theology, bringing them to the forefront of theological inquiry through working with the arts, social sciences and engaging with texts from a more mystical tradition (Coakley 2013: 42-8). Here, I have chosen the writings of Simone Weil 
as a second source to deepen our explorations of how dance could be understood as a contemplative practice in the traditions of Christianity in the West. ${ }^{6}$

\section{Contemplation}

When referring to contemplation what is often assumed is that it is a practice of sitting in stillness and silence. Father Martin Laird, in his Into the Silent Land (2006), explains that:

There are two contemplative practices of fundamental importance in the Christian tradition: the practice of stillness (also called meditation, still prayer, contemplative prayer, etc.) and the practice of watchfulness or awareness (Laird 2006: 4).

Superficially, the idea of dance as a contemplative practice may be contentious both on the basis of it revolving around movement, but also for the lack of silence, as dancing arises from music. However, dance as a practice of awareness was already attested to in the introductory examples. Thus I will commence the exploration here.

In Sarah Coakley's definition of a contemplative practice, she states that it is a method of 'undertaking a radical attention to the Real' (Coakley 2013: 18). She further states that contemplation is a 'commitment to the discipline of particular graced bodily practices which, over the long haul, afford certain distinctive ways of knowing' (ibid. p. 19). Particularly on this point, Coakley's work seems to lend itself well to dancing. Could dancing be seen as one of these graced bodily actions that afford the dancers a connection to themselves and God, ahead. out of which their awareness increases? What is the knowledge that dancing can reveal, and how does a particular form of attention effect dance?

\section{Dance and awareness}

The dance scholar José Gil writes that the experiences of dancers challenge many of the philosophical concepts that have previously been taken for granted. For example, in the movements of a dancer what is experienced is not a sharp distinction between the space of an interior 'subjective' experience over an 'objective' exterior gaze at the body. Rather, movements unfold in the sphere of a living and dancing space of the body. Also, the ontological definition of being and becoming is diluted, as the body propels itself into this space of becoming, always already other than it was a moment ago. ${ }^{7}$ Furthermore, what a dancer does is that he or she becomes, according to Gil, extremely skilled at carving out, moulding and re-creating both the space around her and affecting time through learning to use the energies that are contained in the space of the body. Particularly, Gil's understanding of dance as a transformative process is deeply connected to the fact that humans are desiring bodies - able to assemble, connect, transform and actualise new flows of life and movement (Gil 2001: 67-71).

The descriptions given by Gil give a sense of a high level of agency to the dancing bodies - an agency not only to explore movement and connection with other bodies, but also to express one's needs and desires. Simultaneously though, Gil explains that the space of the body, as the dancer experiences it, is also porous and vulnerable (Gil 2001: 67-71) - topics that

7 See particularly Tiainen and Parikka's reading of Gil (2013: 213-14). 
we will have reason to return to further ahead.

In the dance schoolings that I attended the teaching circulated largely around listening and becoming attentive to the possibilities that lay latent in the space of the body. We were encouraged to listen while dancing - not only to the music - listening to the body, to the emotions and to the thoughts and insights that arrived (LD 2015: sessions 1-3; KR 2014-16: sessions 1-8). All of this was part of the process of increasing our awareness. Carol Harrison, in her The Art of Listening in the Early Church (2013), writes that a distinction can be made neurologically between listening and the conscious activity of speaking and writing. She speaks about this as a shift between what is implicit, emphatically sensed and intuitive, and what is explicitly focused on with the intention of identifying and naming (Harrison 2013: 18-19). The practices we were given to do could very well be understood as exercises in creating a heightened sense of awareness around the implicit, intuitive and emphatically sensed connections, not only with ourselves but also with the world around us.

\section{Radical attention to the real}

The ability to connect with the world around us is in line with the kind of attentiveness also described by Simone Weil in her mystical writings. In Waiting for God (1951), some of Weil's letters and essays are gathered into one book. In her reflections about learning and education she coins the statement that the Christian view of prayer is that it is attention. Here we find a connection between the two different aspects of contemplative practice described earlier.

Weil states that when the totality of the self gives its attention to God, prayer is the result - no amount of emotion or heartfelt feelings can compare to this giving of one's full attention to God. Furthermore, she states that study may be a path to one of the most helpful ways of - training one's attention (Weil 1951: 105). At the same time, Weil also makes it completely clear that even though it is our task to train our attention, the truest form of connection with God comes from our desire. It is through our God-given desire - when we open ourselves to God and let him arrive - that our souls are awakened. In this cooperation of practising mindful attention and giving one's desire to God, we are brought into a space where we can sense and experience the presence of God (ibid. pp. 110-11). Reading Weil, one might assume that attention and prayer, then, are a purely intellectual and mental activity.

However, Sarah Coakley specifies that in the Christian tradition of Origen, Gregory of Nyssa and other mystics, the movements described here, of desire, are actually initiated by the Holy Spirit (Coakley 2013: 91-3). Furthermore, the Christian tradition teaches that the body is the temple of the Holy Spirit, so neither Spirit nor desire can be located within an intellectual or disembodied cognitive sphere (1 Cor. 6:19). It is the Spirit living, moving and acting in us, that commences the movements, and it is only in our co-operation with this force, surrendering into it, that a path can be opened into more intimacy with God (Acts 17:28; Coakley 2015: 123). It is in such a matrix of the location of desire and the capacity to give complete and radical attention to the Real, that I find that dance as both prayer and a contemplative practice may find its roots.

At a later point in the book, Weil also connects the capacity of attentiveness with the ability to love. When we give our attention to something, she says, we are willing to sit with our desire and longing. We sit with these to gain truth and to experience 
the world opening itself to us, without pushing, striving, requiring or even seeking the 'answer' or solution to our quest. Attentiveness in, or with, love is the practice of approximating oneself to the ability to receive and even be completely filled by, the Beloved (Weil 1951: 110-12). What differentiates this from other forms of awareness, is that both Coakley and Weil emphasise the sense of a partnership.

What I am suggesting in light of these statements is that when dancing is in connection to our deepest desire and the dancer is giving his/her attention to God in the dance, dancing may have, and often has had, the function of precisely this kind of opening oneself to the movements of the Spirit. I am not convinced that all forms and kinds of dance do this. However, as the examples from Gil showed, dancing has the capacity to foster this kind of awareness and connect people to their desiring bodies. In this capacity, I think dance may enable not only a connection to the world, but also an intimate opening towards God. It may even awaken the desire that potentially lies latent in each person. ${ }^{8}$ Furthermore, it seems as if the dancers have been taught skills that function as tools for an awareness of these layered experiences of reality. This takes us to the next element in the contemplative journey; the discernment of what happens when the capacity of attention and awakened desire grows.

8 Several women in the group actually spoke about the connection between being depressed, exhausted and 'dead' inside, while coming to a dance practice enabled them to find lust, passion, joy and a deep connection to their desires (LD 3.4.2, 4.2.0; $\mathrm{AI}_{1}$; $\mathrm{AI}_{4}$; $\mathrm{KR}$ 3.2.3; $5 \mathrm{BF} 1,6.2 .0$ ).

\section{The space}

When Coakley writes about contemplation, in particular when addressing questions of learning, and even scientific inquiry, she states that contemplative prayer is a praxis of 'pneumatological dispossession' to truth where the hermeneutical 'stories' that sustain different branches of scientific inquiry are 'revealed' to those who are willing to wait. It is a practice of making 'space' for, not only oneself but also the world. Similar to Weil, she speaks about waiting on God, or simply being open to the unknown (Coakley 2002: 34-5; Coakley 2012a: 7).

Coakley also speaks about the space as a vulnerable space, where materials from our unconscious may rise up and also less desirable elements of our personality and self, be revealed. Coakley further explains, that when this space is approached with the accompaniment of prayer in the Spirit, transformation and expansion into God may occur (Coakley 2002: 3-39). Here, we encounter a topic of tension between Coakley and some of the dancers in my groups as well as writings on dance.

Kimerer LaMothe, for example, when she writes about dancing, seems to stand in line with a view where creativity and connection to the described life-force of dance is altogether 'good' (LaMothe 2018: 1-9, $30-4,49-55,84,90-3)$. In line with that kind of thinking, many of the instructions we were given during the dance practice were phrased as not only listening to our body, emotions, longings and desires but as encouragements to follow what arises. We were asked to explore the incentives we were given through joy, lust, passions and ideas (KR 1.1.2-3, 1.2.1-2, 4.3.1). Along very similar lines, LaMothe is completely averse to any form of Christian asceticism where the movements and impulses of the body are hindered or 'silenced' (LaMothe 2006: 60, 84-5, 220-2, 231). Contrary to 
such a view, Simone Weil speaks about the need for a variety of approaches to our desires.

In a text dealing with human love of the world, Weil returns once more to the themes of attention, love and desire. She states that in our current state of the world, beauty is one of the few places left where we can commune with God. At first glance, Weil's writing about the beautiful and the good may seem like a Neoplatonic idea about the essence or pure ideas of beauty and goodness that should be aspired to in themselves (Weil 1951: 166-7, 171). However, when one reads Weil in more detail, it becomes clear that her views are no mere disembodied intellectual constructs. She writes that beauty is God's invitation to a deepened relationship with the creation, and God's presence in creation. She states:
God created the universe, and his Son, our first-born brother, created the beauty of it for us. The beauty of the world is Christ's tender smile for us coming through matter. He is really present in the universal beauty. The love of this beauty proceeds from God dwelling in our souls and goes out to God present in the universe. It also is like a sacrament. (Weil 1951: 164-5, my italics)

As I understand Weil's writing, it means that matter itself is infused with the love of God and thus, when humans give their loving attention to matter and receive this gift of grace from God, our capacity to attend to God's love increases. Meeting God in his presence in creation we are set into love-motion. Furthermore, what

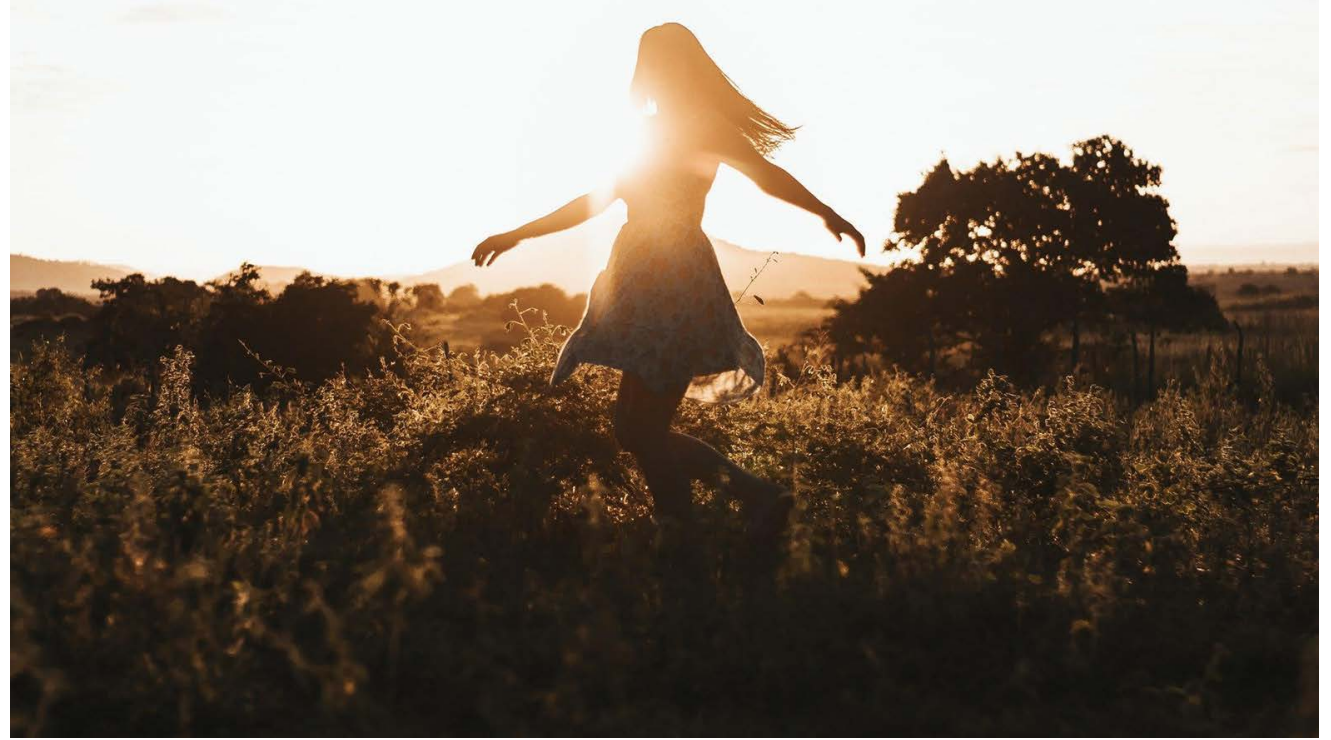

The description of dance as contemplation arises from the fact that the dancers describe that through the sense of Joy that emerged when the dancers where starting to move, they are re-connected to both God and their desires. In the dancing, the bodies seem to be awakening to a lifeforce that activates a heightened sense of meaningfulness and aliveness which enables awareness. Ultimately, dancing brings the dancer on a journey into deeper intimacy with the divine. Photo: Jackson David, Pixabay. 
sacraments do is that they transform the person receiving them. When applying this idea to dancing, several things can be said.

First of all, watching somebody dance may - just as Simone Weil describes that true art can - reveal the beauty and presence of God, in the universe. Such an opening up of reality - of God's incarnation in matter - may also awaken or arouse an increased desire to attain and find connection with the love and beauty that God has to offer us (Weil 1951: 168-9). For Weil, this is the first step of contemplation. Stated in another way, the space of the body has the capacity to draw people to the attention and love of God. Theologically, this raises interesting questions about the interplay of the Spirit, Christ as a being incarnate and God in creation.

Secondly, from the point of view of the dancer, Weil also connects attention, beauty and love, to the work of the scientist. She writes that like the artist, the scientist is tasked to sit with the beauty and presence of God in creation. What will be revealed to the scientist, giving his/her loving attention to the real, is wisdom (Weil 1951: 169). In the Jewish and Christian traditions of thought wisdom, or Sophia, danced and played in front of/with, God before creation (Prov. 8:22-31). ${ }^{9}$ As Weil explains it, the artist, the scholar, the philosopher and the contemplative, can, when they give their loving attention to the created order, start perceiving the connections and relationships that exist between all parts of God's universe (Weil 1951: 169-70, 179).

What I find particularly interesting is that Weil states that physical work - enactments of the body that exhaust us - can

9 See particularly Hildegard of Bingen's interpretation of sapientia and caritas in Newman 1998: 42-9. create a contact with the beauty of the world, 'so full that no equivalent can be found elsewhere' (Weil 1951: 170). As a sensation scientist, and a lover, I am suggesting, that a contemplative dancer also may gain this capacity to experience the intricate details of the entanglement of Wisdom, Beauty and Love, in Creation. Furthermore, these forces can be sensed not only by, but in, the body of the dancer.

Thus, I am suggesting that dance - both as art and as praxis - has the capacity to first awaken and then connect us to our desire, in a way that leads the lover towards the beloved. Dance may also, once we have arrived into this space, be what keeps us engaged with the space of the unknown, helping us to perceive reality 'as it is', behind the veil of familiarity and our normal state of dreaming (Weil 1951: 170). However, from both Coakley's and Weil's point of view, arriving into such a space is not only a pleasant experience. Staying in it will, furthermore, require a lot of practice, for a variety of reasons. Thus, for dancing to truly be a contemplative practice - in this sense - it needs to undress us.

\section{An undressing of the self}

As Simone Weil continues to write about beauty and love and how they can be perceived in creation, she also cautions the reader. Weil says that human love always follows true beauty. However, it easily happens that we turn our attention towards something that is a fraud. Instead of seeing beauty and being inspired or filled by it, humans tend to do one of two things. On the one hand, humans are not content with only receiving beauty. They try to consume or possess it (Weil 1951: 165-6). Once we grasp what was a gift the connection is destroyed. Furthermore, the hurt or emptiness might actually lead to a pursuit of more beauty, in the wrong places. This 
is what Weil calls transference (ibid. pp. 170-6).

On the other hand, humans confuse primary and secondary beauty with each other. In that scenario, humans start chasing things they think are, or will offer them beauty, when the only place where true beauty can be found is in God. What Weil calls secondary beauty are openings to what satisfies our longings. However, 'if we stop short at them, they are, on the contrary, veils; then they corrupt' (Weil 1951: 165). The bottom line, in these descriptions, is that our desires and longings as humans, can, according to Weil, only be fully met, in our encounter with God.

In Weil's line of reasoning, humans are also corrupted by means such as money and power. However, what makes beauty exceptional in this case is that true beauty is an end-goal - something that will be sustained - when all else has fallen away. This means that beauty may shine a light upon things like money and power and make them look like they are more worthy of attainment than they truly are. To make her insights relevant to dance, I will give a couple of examples related to the topics presented (Weil 1951: 165-8).

At one point, Weil writes that money in itself is of no worth. It makes a difference in people's lives only as a means by which we can buy things. However, when beauty sheds lustre on material possessions, these things may instead convey luxury to humans. Luxury, in her view, is much more 'convincing' as a lure to attract people into thinking they need both money and material possessions (Weil 1951: 167). Historically, dancing has played an important role in the discourses on luxury. Creating luxurious banquets with intricate assortments of dances, foods and clothing, have been a part of how the royal houses in Europe competed with each other (Nevile 2008: 375; Green 2011: 24-5, 27). Furthermore, showing off one's status, power and privilege by inviting the most qualified and exotic dancing masters and dance companies into the noble houses has also been a pattern by which dancing has played a part in both political and religious performances between different families and groups of people (Ogilvie 2019: 304-5; Devaney 2015: 154-9). Even when dances are part of religious rituals, one cannot make clear statements about the dancing being 'purely' about communing and communicating with God. Throughout the history of the churches in the Christian West, people have both promoted, as well as shown their ambiguity towards, luxurious performances of various kinds (Arcangeli 1994: 127-55; Webb 2008: 296).

From Weil's point of view, the only remedy to the lure of luxury is the kind of poverty exercised by St Francis. Hers is no romanticisation of poverty - Weil writes equally forcefully that whoever prevents someone from sensing the goodness of God by depriving them of their basic needs is partaking in the creation of horror (Weil 1951: 167-8). At the same time as she does warn people about indulging in pleasures, I do not think she is averse to the idea that God could be revealed in celebration and feasts (ibid.pp. 171-5). Instead, the poverty she is promoting is a social, mental, emotional, spiritual and bodily practice.

Interestingly, from the point of view of dance, St Francis is known to have danced in at least two different ways. In the Christian traditions St Francis is described firstly, in a more metaphorical sense, as a vagabond and jongleur, signifying a person who can move more freely outside of the social and political norms and concerns of the time (Ziolkowski 2018: 58, 97-100). When dancing, as King David does, in front of the Ark in the Hebrew Bible 
(2 Sam. 6; 1 Chr. 13), a person was considered to be stripped of what we today might call one's ego (Clopper 2001: 56-7). Dancing, truly and authentically in front of God - not caring about the gaze of social or cultural constraints on his half-naked body - St Francis and King David were (at least in the medieval setting) ideals of what a person approaching God wholeheartedly may look like.

When the leaping dance of David and the nakedness of St Francis are used as metaphors this does not mean that, either culturally or socially, churches or communities of Christians, today or in the past, would be comfortable, or accepting, of somebody adopting this kind of behaviour in their public dancing. However, such ambiguity about public dance in a certain format does not prevent people from using - as some of the practitioners I met do more untamed, unruly and free forms of dance in a more intimate sphere, with God (KR BK4, 1.2.2, 3.1.0, 3.2.1, 7.2.0; $\mathrm{AI}_{5}$; AI6). In my examples, it is clear that the dancers are expressing both emotional states and physical actions in a way where they offer their selves honestly to, or in front of, God. Their expression is sometimes even clearly stated to be an offering - a gift for God and a letting go $\left(\mathrm{AI}_{7}\right)$.

Furthermore, when the church setting is one where charismatic influence is more common, even the public sphere may be able to hold some of this 'rowdiness' (Coakley 2013: 112-13). Here again, St Francis is shown to have been an exception to the expected behavioural patterns of his peers - particularly when he is described dancing in his physical body, right in front of the Pope. The situation is explained as him becoming overcome by the Spirit. As he becomes overwhelmed by joy and the presence of God, his feet start to move (Wolf 2003: 81-2). The effects of the presence of the Holy Spirit on the bodily actions of a person is a topic which, although relevant to contemplation, needs to be dealt with on a later occasion.

What I have attempted to describe are instances where people are being drawn into a dance - either metaphorically or physically - where God leads the practitioner into unknown territory, to places and spaces where $s /$ he is exposed to the unpleasant confrontation of becoming stripped of one's 'normal' lines of defence be they social status, money, material possessions, or ideas about being 'somebody' in the world. Dancing may be a very concrete pattern for how a contemplative path is deepened through exploration and excavation of the self. In such a process, it seems as though dance carries a particular ability to place people in a vulnerable position. It is in this capacity that I would describe a certain kind of dancing as a preparation of the self for a receiving of the unknown.

\section{Asceticism}

When Weil goes on to speak about power, it becomes clear that what is needed on the contemplative path is more than merely an 'undressing' of the social constructs around the self. In her examples of power, Weil's depictions become even more intricate in their details. She writes that when the sense of power is coupled with beauty: what emerges is an idea that we may, and can, create order. This means that instead of seeing and celebrating how the universe is full of order and beauty, humans start forcing specific patterns into existence (Weil 1951: 168). This dimension of alluring temptations may take its form in physical behaviour, as when, for example, people in church settings have rigorous and legalistic ideas about how the liturgy should be conducted - or, in the example given by Weil, architecture is created. 
However, as I see it, the question of forcing patterns is very much related to mental activities. When Weil speaks about the ordering of the universe according to particular patterns, we are back to the question of what kinds of 'stories', concepts and ideas do we have about the world, and ourselves in it. One example of this is, for example, Eva Kittay's writing about how we may gain insight into the experiences and worlds of others. She speaks about a deepened knowing which is only possible when we are passionately attentive to every living creature (Kittay and Carlson 2010: 440). ${ }^{10}$ To this kind of reasoning Coakley adds that what is needed in both human interactions and science is more than an intentional design on empathy. Ascetic contemplative practice is more discomforting, more destabilising to our settled assumptions and it even goes as deep as 'purging' our desires (Coakley 2013: 6, 19-20, 26-7, 48). Coakley would not deny that living a contemplative life may lead to a more loving gaze, actions of mercy, patience and kindness. However, she is wary about our preset, idolatrous tendency to make the 'other' into our own image, instead of letting the unknown shatter us (ibid. pp. 20, 42, 51-2, 68, 84-5).

Forcing patterns upon the body is something that was also discussed amongst the dancers. For them, it was essential to be part of a 'living' tradition that is open to receiving God in any form in which the divine may appear. ${ }^{11}$ This capacity was

10 Kittay brings forth the example of the Nobel Prize winner Barbara McClintock. In her work, the ability to be passionately attentive to the 'other', gave her insights into even the life of individuals she had no common language with. Through time, this practice even changed her perception so that she could sense the experiences of that other.

11 In some exercises that included Jesus often contrasted with the rigid formulae of both movement and language imposed on the intuitive and tacit ability to sense what is needed in each unique moment. Both socially, culturally and on a more personal level, we may force different movement patterns on our bodies in order to make them more 'able', 'lean', 'fit', 'sexy', 'athletic' or 'competent'. As I understand LaMothe, this is what she is strongly opposed to when she makes her statements against asceticism.

However, when Coakley explores both Nietzsche and Foucault on the question of using institutionalised power - be it by the church or the state - on bodies, the question is not about the repression of desires or manipulation and control of sexuality. She draws a distinction between true asceticism and false repression at the same time as she makes it clear that hers is no armchair academic ascetic endeavour (Coakley 2015: 9-18). Instead, what is at stake is our gendered, racialized and distorted views of reality that are embedded in the culture and society we live in.

Coakley speaks about purging and reordering of our passions, precisely as she is aware of how intricately and complexly interwoven together human desire, sexuality and power are (Coakley 2013: 342-3). Contrary to authors like Linn Tonstad and the commentators on Coakley's work in Modern Theology, 30(4), published in 2014, I would not argue that Coakley's thinking shows a preference for some kind of intellectual unknowing and silence in the contemplative life over embodied and sociallylocated practices (Tonstad 2015: chapter 3). Instead, her thinking seems to be deeply embedded in the actual practices of ascetic

looking as a woman, God speaking through the actions of a person with disabilities or sensing the Holy Spirit in an encounter with a living tree (KR 2.3.1, 3.1.1, 3.1.2.1, 8.3.0). 
contemplation. This can be seen on two levels.

First of all, when Coakley speaks about ascetic contemplative practices, it is not only a question of sitting in daily stillness and silence. Instead, she states that there are a plethora of different practices that help to sustain a contemplative life. These practices include, but are not restricted to; meditation on the scriptures, fasting, charity and acts of mercy towards the poor, engaging with the sacraments, participation in public worship and private devotion (Coakley 2015: 124). To start with, these are all bodily acts, and most of them are done in community - either in a physical and shared space, or in the theological sense of taking part in the 'community of the Saints' - people past and present - that share in this path.

Continuing on this same theme, Coakley explains that 'bodily acts of worship and attention (even if the mind is distracted) have their own integrity and effect' (Coakley 2015: 115). Building on Talal Asad and others, she pinpoints the importance of habits from the point of view that what we do with our bodies, creates not only certain mental patterns of reasoning but enables specific beliefs and ideas (Coakley 2018). Thus, as I read her, the body is primal. Both our individual and communal bodies carry stories, represent ideals, express wishes and hopes. Looking at this from the point of view of dancing, a dancer knows that in order to learn a choreography there is no other way than to repeat it over and over again. It is also equally true, that once a movement pattern has become a habit it is so ingrained in us that it takes a lot of energy and practice to break it. What I hear Coakley stating is that it is like this with everything in our lives.

Most importantly, though, many of the movement-patterns of our lives we have picked up from thoughts and ideas that were unwillingly transferred to us and given without intentional reflection upon them. We are situated in communal worship practices - be it through the advertisements we look at, the school system we participate in, or the national identity we are brought into (Smith 2009: Part 1). Thus, if we seek any kind of change, we need to start with taking an inventory - what is it, that we really do, think, feel, sense, see, hear, taste, intuit?

As I have explained, the praxis of listening to the body, but also following movements of bodies, may awaken our ability to sense and perceive these larger movement patterns as well. However, I find it crucial to pinpoint that many of the practitioners expressed that it was in the solitude and silence - the withdrawal from a community and breaking with habits - where they were able to identify the social and cultural movement-patterns imposed on them (LD 3.3.2, 3.3.3, 3.4; KR AI1, AI6, AI7). If there was no 'dispossession to', nothing new was revealed.

Coakley clarifies that the path of ascetic practices is not to erase, but to identify the passions and desires that are moving within us. She writes:

When the ascetic life works, and works well, it unifies, intensifies and ultimately purifies desire in the crucible of divine love, paradoxically imparting true freedom precisely by the narrowing of choices. (Coakley 2015: 6)

Both in creating distance to something and someone and in limiting one's options, a new layer of awareness was created. In the schooling I attended these elements were created both through having solitary time in nature, staying silent in community, shifting from movement to stillness and 
being intentional with our communication with the outside world during the dance retreats. Sometimes these imposed 'rules and regulations' also created tension within the dance community, where some practitioners were, more or less, willing to put themselves 'under' the authority of a communal praxis of a narrowing of choices. As I see it, some of this tension could have been ameliorated had the leaders expressed a clearer understanding of the role of unconscious behaviours or layered functioning of desires in dancing.

\section{From consciousness to unconscious behaviour}

The last topic I want to address in this article is the question of when a search for awareness and consciousness, seems to turn awry. The risk with emphasising how the practice of dancing may create an increased awareness of self and others, as I have already pointed out, is not only that dancers are lured into thinking that they can control or form the world around them to a greater extent than is possible.

Particularly situating one's awareness into an esoteric realm of a diffuse divine communication may actually lead either to personalities like Gurdjieff, stepping into a community of dancers and applying highly questionable methods for spiritual advancement, or the creation of communities of people that either consciously or unconsciously, use their dance to promote a sense of spiritual, religious, or ethnic superiority. The ethnic and racial discrimination practised within many of the modern dance movements and also Christian religious dance groups, have been well documented elsewhere (Schwan 2017: 23; Karina and Kant 2003; Cusack 2020; Webb 1987: 3324). Here, I only want to address the fact that even a writer like Simone Weil may harbour in her speech about the non-white

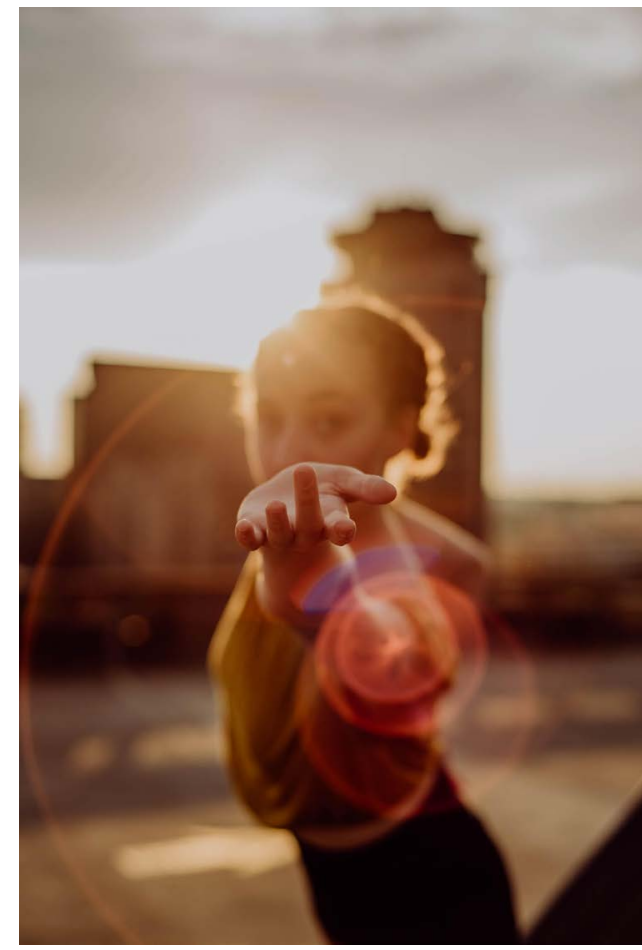

The dancers often explained to me that they found their intimate connection to the Divine through the movements and the stillness as well as in the constant moves made during the schooling from community exercises to times in solitude and silence. (Dancer in image is not from the schooling.) Photo by Olivia Bauso from Rooftop dance photography session in Rochester, NY.

races, something of a romanticising and universalising attitude towards the uncultured and non-Christian communities of the world.

Why I find particularly the writings of Sarah Coakley so compelling, is that it is precisely the disturbing desires and unconscious aspects of our imaginaries, that she argues the practice of ascetic contemplation may address. What has been mentioned only briefly so far is that Coakley borrows insights not only from Foucault on the social dimensions of our bodypolitic, she also borrows from Freud, when she speaks about our individual and communal habits. Not all of our thoughts, 
actions, emotions and decisions are at the level of the pre- or sub-conscious so that we can willingly bring them up to awareness. Instead, Coakley writes about the erotic tug that impinges on us daily:

Such manipulations are diffuse, permeating socially constructed longings of which we are barely conscious but which disturbingly exercise our wills and imaginations. These include the desire to dominate, to subjugate, to consume and own, and to control sexually, racially and in other ways. (Coakley 2015: 9)

It is when we move to the unconscious levels of our self that, as I see it, functioning ascetic contemplative practices make a real difference. If a dancing community is instructed to bring up everything and anything that is experienced in the dancing on their fellow dancers, this can also become an extremely disturbing and destructive environment. On the other hand, if sitting or moving in the space of the unknown allows us to come in contact with the even deeper layers of our personalities, this can also have healing effects. If our socially ingrained habits - such as a racialized imagination can be safely brought into the light of day, contemplation becomes an indispensable tool for both social justice and environmental change (Coakley 2015: 9).

It is in this erotic lure of the unconscious where dancers need to learn from the theological teachings of contemplation. To lay out all of our conscious and unconscious desires in front of God - not our vulnerable neighbour - is a life-long practice that requires uncomfortable listening.

In conclusion, this article has shown that dancing can very well be included in the contemplative practices of the Christian traditions of the Latin West. It has also demonstrated that when following the dancing practised in the Church of Sweden context, and the experiences described by the dancers, a deepened understanding of different stages of contemplation can be noted. In the beginning, dancing seems to awaken people - make them alive - and help them become aware of their relationship with themselves and God. Once a more conscious connection has been made with desire, this may lead the practitioner into more intimate layers of dancing with and for God. Sometimes this dance even leads the dancer to the brink of transformation -- a space of purging and leaving behind certain mental habits, structural movement patterns, or repetitive negative 'stories'.

Facing the unknown is something that may be practised through dance, and thus dancing may even help in bringing up preand sub-conscious layers of our personalities. However, the Christian theological traditions also remind practitioners of contemplation that not all of our desires are of a kind that it is wise to let them run freely. There is one safe space where they can be brought, and that is, in front of the Creator. Coakley describes that the kind of intimacy and vulnerability that a purging of our desires needs is not possible to do on our own. It requires, Coakley says, that we have a vision of a life in Christ that may carry us through the darkness. The path will furthermore be very demanding, requiring that we seek support also from others. Most of all, though, it is impossible to do without the guidance of being led by the Spirit on a daily basis. Being led in this way is something that the dancers I encountered spoke about themselves learning and teaching through dance. One of the main sources of hope, for this journey, is thus to dance and live together with women like Macrina, who - after a lifetime of faithful observation - according to her brother, Gregory of 
Nyssa, was transformed already on earth into more heavenly features (Coakley 2002: 85; Coakley 2012b). It is this transformation of the Self, which in the Christian tradition is called deification - that may end with us all dancing in incarnational bodies in a new creation.

Laura Hellsten is a postdoctoral fellow in the Stiftelsen Åbo Akademi Centre of Excellence BACE at Åbo Akademi University. There she works as an ethicist ethnographically participating in a trans-disciplinary research group studying the functions

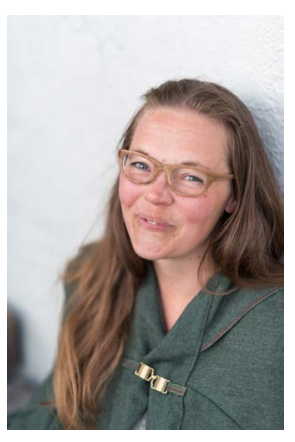
of cells. She currently also leads the project 'Forcing the Impossible - Avtryck i det Okända', which brings together artists and researchers around the theme of science communication. She has written articles around current and historical practices of dance in Western Christian theological traditions. Her doctoral thesis Through the Bone and Marrow: Re-examining Theological Encounters with Dance in Medieval Europe, will be published by Brepols in 2021. Together with Nicole des Bouvrie, she leads the study circle on feminist philosophy at the Nordic Summer University and functions currently as the study-circle coordinator on the board of NSU. She furthermore always refers to her cat Moses as being one of the most important teachers of theology in her current life situation.

\section{References}

Adams, Doug, and Diane Apostolos-Cappadona. 2001. Dance as Religious Studies (Eugene, OR: Wipf and Stock Publishers).

Arcangeli, Alessandro. 1994. 'Dance under trial: the moral debate 1200-1600', Dance Research, 12(2): 127-55, doi: <https://www.euppublishing.com/doi/ pdfplus/10.2307/1290992>.

Barrett, Estelle, and Barbara Bolt. 2013. Carnal Knowledge (London: I.B.Tauris).

Borges da Costa, Ana Luica, and Diane L. Cox. 2016. 'The experience of meaning in circle dance', Journal of Occupational Science, 2: 196-207.
Calhoun, Adele Ahlberg. 2015. Spiritual Disciplines Handbook (Downers Grove, IL: InterVarsity Press).

Clopper, Lawrence M. 2001. Drama, Play, and Game (University of Chicago Press).

Coakley, Sarah. 2002. Powers and Submissions: Spirituality, Philosophy, and Gender (Oxford: Blackwell Publishing).

- -2012a. 'Lecture 1: Stories of evolution, stories of sacrifice, The Gifford Lectures, $<$ https://www.abdn.ac.uk/sdhp/events/ gifford-lectures/sarah-coakley-524.php> (accessed 18.4.2019).

- 2012b. 'Lecture 6: Reconceiving "natural theology": meaning, sacrifice and God', The Gifford Lectures, <https://www.abdn.ac.uk/ sdhp/events/gifford-lectures/sarah-coakley-524.php> (accessed 18.4.2019).

-_2013. God, Sexuality, and the Self: An Essay 'on the Trinity' (Cambridge University Press).

--2015. The New Asceticism: Sexuality, Gender and the Quest for God (London: Bloomsbury Publishing).

- 2018. 'Christian worship and desire', Queens' Birmingham Annual Lecture, 25.6.2018, <http://www.queens.ac.uk/ uploads/policies/Sarah-Coakley-lecturetext.pdf?fbclid=IwAR13kzBzTDLLEy2MT jhFbSxwwLpouXedbKTH3ue9KQoT3nionHJU8rQogP8> (accessed 18.4.2019).

Cusack, Carole M. 2020. 'G. I. Gurdjieff on health and healing: hypnotism, sacred dances, diet, physical labour, and drugs', in Health and Healing in Minority Religions, eds. Eileen Barker (London and New York: Routledge.

Devaney, Thomas. 2015. Enemies in the Plaza (Philadelphia, PA: University of Pennsylvania Press).

Gil, José. 2001. Movimento total: $O$ corpo e a dança (Lisboa: Relógio d’Água).

Green, Helen. 2011. 'Defining the city "trumpeter": German civic identity and the employment of brass instrumentalists, c.1500, Journal of the Royal Musical Association, 11(1): 1-31, doi: <https://doi.org/10. 1080/02690403.2011.562714>.

Harrison, Carol. 2013. The Art of Listening in the Early Church (Oxford University Press).

Karina, Lilian, and Marion Kant. 2003. Hitler's Dancers: German Modern Dance and the Third Reich (Oxford: Berghahn Books). 
Kittay, Eva Feder, and Licia Carlson. 2010. Cognitive Disability and Its Challenge to Moral Philosophy (Hoboken, NJ: John Wiley \& Sons).

Kokkinen, Nina. 2020. 'Initiation i korsningen mellan konsten och det esoteriska', in Andens rikedomar. Esoterismen och den finländska konstvärlden 1890-1950, eds. Nina Kokkinen, Lotta Nylund and Camilla Ahlström-Taavitsainen (Helsinki: Parvs), 8-23.

Kokkinen, Nina, and Lena Nylund (eds.). 2020. Spritual Treasures: Esotericism in the Finnish Art World 1890-1950 (Helsinki: Parvs).

Laird, Martin. 2006. Into the Silent Land (Oxford University Press).

LaMothe, Kimerer L. 2006. Nietzsche's Dancers (London: Macmillan).

- -2018. A History of Theory and Method in the Study of Religion and Dance (Leiden: Brill).

Mead, George Robert Stow. 1913. 'Ceremonial dances and symbolic banquets in medieval churches', The Quest, January 1913 [reprinted in Sacred Dance in Christendom, London: J.M. Watkins, 1926].

Modern Technology, 30(4), 2014, doi: <https://onlinelibrary.wiley.com/ toc/14680025/2014/30/4>.

Nevile, Jennifer. 2008. Dance, Spectacle, and the Body Politick, 1250-1750 (Bloomington, IN: Indiana University Press).

Newman, Barbara. 1998. Sister of Wisdom (Berkeley, CA: University of California Press).

Ogilvie, Sheilagh. 2019. The European Guilds (Princeton University Press).

Schwan, Alexander. 2017. 'Ethos formula: liturgy and rhetorics in the work of Ted Shawn', Performance Philosophy, 3(1): 23-39, doi: $<$ https://doi.org/10.21476/pp.2017.31168>.

- 2019. 'Theologies of modern dance', Dance Today, 36: 75-8.

Smith, James K. A. 2009. Desiring the Kingdom (Cultural Liturgies) (Ada, MI: Baker Academic).

Taylor, Margaret Fisk. 2009. A Time to Dance (Eugene, OR: Wipf and Stock Publishers).

Tiainen, Milla, and Jussi Parikka. 2013. 'The primacy of movement: variation, intermediality and biopolitics in Tero Saarinen's HUNT, in Carnal Knowledge: Towards a 'New Materialism' through the Arts, eds. Estelle Barrett and Barbara Bolt (London: I.B. Tauris), 205-24.
Tonstad, Linn Marie. 2015. God and Difference (London and New York: Routledge).

Webb, James. 1987. The Harmonious Circle: The Lives and Works of G. I. Gurdjieff, P. D. Ouspensky, and Their Followers (Boulder, CO: Shambhala Publications).

Webb, Ruth. 2008. Demons and Dancers (Cambridge, MA: Harvard University Press).

Weil, Simone. 1951. Waiting for God, trans. Emma Craufurd, with an Introduction by Leslie A. Fiedler (New York, London: HarperPerennial).

Wolf, Kenneth Baxter. 2003. The Poverty of Riches (New York: Oxford University Press).

Ziolkowski, Jan M. 2018. The Juggler of Notre Dame and the Medievalizing of Modernity. Vol. 3: The American Middle Ages (Cambridge: Open Book Publishers). 